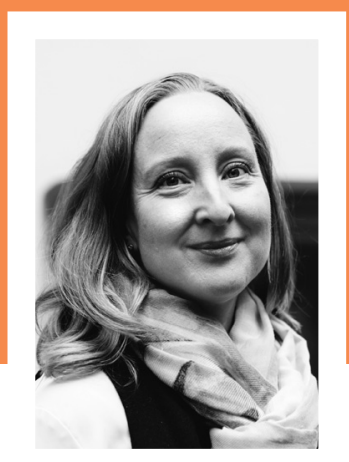

\title{
P̈̈̈̈KIRJOITUS
}

\section{AVOIMUUS VAHVISTAa VERTAISUUTTA JA YHTEISÖLLISYYTTÄ}

\section{$\mathrm{T}$}

TÄStÄ nUmerosta ALKAEn Aikuiskasvatus on avoin julkaisukanava monitieteisille ja -äänisille tiedeartikkeleille, näkökulmille ja puheenvuoroille. Lehti ilmestyy edelleen neljä kertaa vuodessa, mutta digitaalisesti Tieteellisen seurain valtuuskunnan (TSV) ylläpitämällä Journal.fi-sivustolla. Avoimuus lisää tutkitun tiedon näkyvyyttä ja saatavuutta.

Nyt, kun tärkeä askel avoimuuden suuntaan on otettu, löytyykö tiedeyhteisöstä rohkeutta myös julkaisuprosessin avaamiseen? Seuraava pohdinnan arvioinen asia on vertaisarvioinnin avoimuus, jossa sekä arvioitsijat että kirjoittajat tietävät toisensa. Laadukas tiedeartikkeli syntyy kirjoittajien, toimituskunnan ja vertaisarvioitsijoiden yhteistyönä. Avoin arviointi avaisi julkaisuprosessia aikuiskasvatuksen tutkijoille, aikuiskouluttajille, opiskelijoille ja päätöksentekijöille.

'VERTAISUUS' YMMÄRRETÄÄN yleisesti samankaltaisuutena, vastavuoroisuutena ja tasa-arvoisuutena. Tieteellistä tutkimusta arvioitaessa vertaisiksi katsotaan aihepiirin tutkijoiksi kouluttautuneet, usein tohtoriksi väitelleet tai vähintään itsekin tieteellisiä artikkeleita julkaisseet asiantuntijat. Aikuiskasvatuksessa noudatetaan kaksoissokkoarviointia: kumpikaan arvioinnin osapuoli ei tiedä toisen henkilöllisyyttä. Toimituskunta lukee käsikirjoitukset anonyymeina.
Tieteellinen julkaiseminen on tärkeä osa tieteellistä meritoitumista. Arvioitsijat ja arvioitavat ovat osa tiedeyhteisöä, joka on kilpailullinen ja jossa vallitsee tieteellisiin ansioihin perustuva hierarkia. Arvioitsijat kerryttävät kirjoittajien tavoin omia akateemisia ansioitaan. Tutkija Riitta Jytilän ja apulaisprofessori Mikael Laakson tuore Selvitys avoimesta vertaisarvioinnista kotimaisen tiedejulkaisemisen kentällä -julkaisu puoltaa nimettömyydestä luopumista sillä, että arvioitsijoiden työ tulisi näkyväksi ja hyvät lausunnonantajat saisivat ansaitsemaansa arvostusta. Avoimuuden sanotaan lisäksi vähentävän asiattomuuksia, jotka johtuvat tutkijoiden välisestä kilpailusta.

Mitä onnistumisen edellytyksiä avoimella arvioinnilla on? Tiedeyhteisön sosiaalisissa rakenteissa joillakin tutkijoilla on valtaa vaikuttaa toisten tekemisiin ilman, että sama pitää paikkansa toisinpäin. Vertaisarvioinnissa lausunnonantajalla on valtaa siihen, millainen tutkimus ja millaiset jutut ylittävät julkaisukynnyksen. Lausunnon vastaanottaja, kirjoittaja, voi taas olla korkeammassa asemassa kuin arvioitsija.

Arvioitsijaksi suostuminen edellyttää statusta ja valtaa koskevien suhteiden punnitsemista. Siksi on vaikea kuvitella akateemiselle uralle pyrkivää, tuoretta tohtoria allekirjoittamassa nimellään kriittistä arviota arvovaltaiselle professorille. Nimettömyys suojaa kirjoittajan lisäksi arvioitsijaa. 
Avoimuuden haasteita voidaan ratkoa lisäämällä avoimuutta vielä enemmän. Ensinnäkin lausunnot voi julkistaa, jolloin tiedeyhteisö pääsee arvioimaan palautteen vaikutusta artikkelin kokonaisuuteen. Toiseksi avoimuuden myötä lausunnonantajalla ei enää ole varaa ylimalkaisuuteen, piikittelyyn eikä mielistelyyn.

KANSAINVÄLISISSÄ JULKAISUISSA avoimuuden ideaa on kehitetty yhteisöllisen vertaisarvioinnin suuntaan. Äärimmäisen avoimuuden omaksuneissa julkaisuissa artikkelikäsikirjoitukset julkaistaan ilman ennakkoarviointia ja avataan samalla julkiseen vertaisarviointiin, johon kirjoittajat itsekin osallistuvat ja jonka perusteella he muokkaavat tekstiään. Toisinaan avointa kommentointia edeltää perinteinen vertaisarviointi.

Avoimuuden tarkoitus on nimenomaan laajentaa vertaisuuden ja yhteisöllisyyden ulottuvuuksia arvioinnissa. Yhteisöllisesti toteutettu tiedejulkaisujen arviointi lähestyy joukko- tai parviälyn ideaa tiedon jakamisesta, yhteiskehittelystä ja vertaisilta oppimisesta.

Esimerkistä käy avoimeen lähdekoodiin perustuvien tietokoneohjelmien kehittäminen virtuaalisissa käyttäjä-kehittäjäyhteisöissä. Kehitettävä koodi on jatkuvasti vertaisten avoimesti saatavissa, testattavissa ja muokattavissa. Yhdessä tekeminen auttaa löytämään ja korjaamaan virheet nopeammin ja laadukkaammin kuin mihin kukaan yksin tai perinteistä testaamista noudattaen pystyisi. $\mathrm{Ne}$, jotka osaavat arvioida taitavasti muiden tekemisiä ja parantaa työn laatua, saavat yhteisössä mainetta ja arvostusta.
Samaan tieteen laadunvarmistuksen joukkovoimaistamiseen ja arviointinäyttöjen avulla alan asiantuntijaksi noteeraamiseen tähdätään julkaisujen arviointikäytäntöjen avaamisessa.

MIHIN AVOIN VERTAISARVIOINTI voisi Aikuiskasvatuksessa johtaa? Onko mahdollista, että tiedejulkaisemisesta tulisi vertaisuutta ja yhteisöllisyyttä vahvistava prosessi?

Avoimessa prosessissa arvostuksen saavuttaa jakamalla lausunnoissaan parasta asiantuntemustaan tiedeyhteisön hyväksi. Käsikirjoitusten arviointi yhteiskehittelynä estäisi kilpailevien tai kiistelevien tutkijoiden keskinäisen nokittelun, tai ainakin keskustelussa olisi nykyistä useampia osallistujia välittäjinä. Avoimuus edistäisi lisäksi arvioitsijoiden ja kirjoittajien verkostoitumista julkaisumaailmaa laajemmilla kentillä.

Julkaisemme tässä numerossa kaikkien vuonna 2018 vertaisarviointiin osallistuneiden nimet. Näin teemme arvioitsijoiden työtä näkyväksi ja kiitämme lämpimästi tehdystä työstä julkaisuidemme korkean tieteellisen tason, luotettavuuden ja luettavuuden puolesta.

\section{Ulpukka Isopahkala-Bouret}

\section{Lisää aiheesta:}

Jytilä, R. \& Laakso, M. (2019) Selvitys avoimesta vertaisarvioinnista kotimaisen tiedejulkaisemisen kentällä. Tieteellisten seurain valtuuskunnan verkkojulkaisuja 5.https://doi.org/10.23847/978-952-599516-9. Helsinki: Tieteellisten seurain valtuuskunta.

Kouvo, T. (2018). Vertaisarvioinnin uusin suunta on avoimuus. Aikuiskasvatus 38(3), 246-247. 